\title{
Pioneering women archivists in England: Ethel Stokes (1870-1944), record agent
}

\author{
Elizabeth Shepherd ${ }^{1}$ (D)
}

Published online: 21 November 2016

(C) The Author(s) 2016. This article is published with open access at Springerlink.com

\begin{abstract}
This paper explores the life of Miss Ethel Stokes who was significantly involved in several major historical, literary and archival enterprises in early twentieth-century England. She established the Records Preservation Section of the British Records Association, she edited historical records and wrote for publication in works of reference including local and British Record Society volumes, the Victoria County History of England and the Complete Peerage, and she established an independent and successful business as a record agent, Stokes and Cox. The article is the first in a planned series which will study the lives and professional contributions of pioneering women archivists in England. An explanation of the background to this work, a literature review and a justification of the need for this new field of study are articulated in Shepherd's chapter, 'Hidden voices in the archives: pioneering women archivists in early twentieth century England' (Shepherd in Engaging with archives and records: histories and theories. Facet Publishing, London, 2016). In line with the collective biographical approach outlined there, this paper will consider Miss Stokes's family and educational background, her friendships, charitable work and her professional activities and projects, seeking to set her into the context of her own times.
\end{abstract}

Keywords Archival history · Ethel Stokes · Joan Wake · Women archivists · Twentieth-century archives in England

Elizabeth Shepherd

e.shepherd@ucl.ac.uk

1 Department of Information Studies, UCL, Gower Street, London WC1E 6BT, UK 


\section{Introduction}

'If there is one person to whom historians of the present and the future should acknowledge their debt, that person is Ethel Stokes' (Wake 1954, p. 7).

Joan Wake wrote a tribute to her friend, Miss Ethel Stokes (1870-1944), in which she described her as 'the prime mover, the chief instigator, in the truest sense the real founder of the biggest movement for English history since the passing of the Public Record Office Act of 1838' for her work in establishing a system for the preservation of the local archives around England through the Records Preservation Section of the British Records Association (Wake 1954, p. 1). This paper, which will explore the life of Ethel Stokes, is the first in a planned series which will study the lives and professional contributions of pioneering women archivists in early twentieth-century England. An explanation of the background to this work, a literature review and a justification of the need for this new field of study are articulated in Shepherd's chapter, 'Hidden voices in the archives: pioneering women archivists in early twentieth century England' (Shepherd 2016). In line with the methodological approach outlined there, the construction of an individual life history of Ethel Stokes is combined with an historical overview of educational and archival developments. An analysis of Miss Stokes's professional life is set into educational, cultural, social and family contexts, and by examining her friendships, voluntary and charitable work, and professional activities and projects, tracking her social networks and exploring her personality we can begin to understand her place in the history of our profession. These individual life stories will together comprise a collective biography which reconstructs the different communities, government and educational institutions, the network of lives, social relationships and individual interests which combined to bring about emergence of the archival profession in early twentieth-century England. Links and synergies between the different lives are explored to bring out their joint contributions to the development of the profession in England.

The research for this article drew on primary and secondary sources. Significant among the primary sources were the archives of the British Records Association held at London Metropolitan Archives (LMA) and the letter and account books of Stokes and Cox, letters and other archives held in the Joan Wake Collection at Northamptonshire Record Office (NRO). Of particular value were letters from friends and colleagues written to Joan Wake when she was preparing her memoir of Ethel Stokes. Miss Stokes was significantly involved in several major historical, literary and archival enterprises of the early twentieth century: as well as establishing and running the Records Preservation Section of the British Records Association (BRA), she edited historical records and wrote for publication in works of reference including local and British Record Society volumes, the Victoria County History of England ( $\mathrm{VCH})$ and the Complete Peerage, and she established an independent and successful business as a record agent, Stokes and Cox. 


\section{Family background and schooling}

Ethel Stokes was born on 17 January 1870 in Holloway, London, to Edwin James Stokes (1844-1916) and Elizabeth (Fanny) Augusta Stokes, formerly Baker (1864-1933). The family was middle class, living in St George's Villas, Finsbury, in 1871 (UK Census), with a Welsh girl, Sarah Griffiths, as a general servant. Ethel's father was a stockbroker's clerk in 1871, who progressed to a stockbroker's agent by 1891 . Her mother was described at the age of 24 as 'professor of music and Associate of the London Academy' (UK Census 1871). Joan Wake's draft memoir notes that Ethel's father had various stories about the family, but it may be that her grandfather was a boot maker and leather merchant in London (NRO, Box 104). Ethel's brother, Durham, was born in 1871. At the age of 9, he was boarding at a school in Napier Lodge, Margate, Kent, run by Eleanor Williams, a governess, who employed two further governesses Kate Lindsay and Constance Smith, to teach 34 boys who ranged in age from 7 to 12 years old. The school's household was supported by six servants (a cook, wardrobe keeper, housemaid, two laundry maids and a page boy) (UK Census 1881). The Stokes family lived in Girdlers Road, West Kensington, from about 1885 until 1890 (Notting Hill and Ealing High School Archives (NHEHS), Admissions Register, Old Girls Association). By 1891, the family had moved to Abbotsford in Torrington Park, built in 1865, in the more rural suburb of Friern Barnet, Enfield (UK Census 1891). The area had been gradually developed after the building of Colney Hatch station and the opening of the Metropolitan Railway in 1863 and attracted commuters to live 'in small semidetached houses, described as smart villas..., or in superior terraced houses with bay windows' (Baggs et al. 1980).

Durham followed his father's career, initially as a stockbroker's clerk. In 1896, he married (Alice) Ethel Leon and they had three sons (UK Marriage Index; Woolheim 2004). The youngest son, Adrian Durham Stokes, writer and painter, was born in 1902. The census for 1901 showed that Durham lived in Radnor Place, Bayswater, London, although his family is not listed. He was described as 'a gent' and a stockbroker and had four servants (parlour maid, house maid, maid and cook) (UK Census 1901). His life seems to have been fairly conventional. He became wealthy and successful, having established a stockbroking firm, Durham Stokes and Co, in Old Broad Street, City of London (NRO, Box 104). Durham travelled abroad in the 1920s and 1930s by ship to Marseilles, France, to New York and Montreal, Canada, and to Genoa, Italy (Ship Passenger Lists, 1925, 1928, 1932). By 1945, he lived in Porchester Terrace, Paddington. After retirement, he lived at the Calverley Hotel, Tunbridge Wells, until his death in 1957 at the age of 86 (UK Death Index). His estate at probate was valued at $£ 132,45117 \mathrm{~s} 5 \mathrm{~d}$.

Ethel's education and family life, however, followed a very different course, and by the time of her death in 1944, she and her brother had not been in touch with each other for many years. Her nephew AD Stokes wrote to Joan Wake in 1954 that he had 'always wanted to know more about her. It sometimes happens she was not very forthcoming with her family, with good reason' (NRO, Box 104). Exactly what the 'good reason' was, the author has been unable to discover. When Ethel was 11 years 
old, she boarded at a Margate school run by Ada Aubrey, school mistress, and wife of Alfred, a professor of music (UK Census 1881). As well as their own daughters, Mrs Aubrey taught six boarders, all girls, ranging in age from 8 to 18. According to Joan Wake's draft memoir, Ethel Stokes recounted that her father told her to read any book she liked and to go where she wanted, so she walked all around London by herself aged 12 years (NRO, Box 104). Ethel attended Miss Sutton's Collegiate School, Cathcart Hill in Highgate. In the spring term of 1885, she started as a pupil at the Notting Hill High School, one of the first founded by the Girls' Public Day School Company (later Trust) (NHEHS, Admissions Register).

In the mid-1800s, few girls were educated at school: most who could afford it received some home education with a governess, learning sewing, French, music, drawing and perhaps home economy. In 1872, the Girls' Public Day School Company was formed to provide high schools in large towns which would offer girls education in music, mathematics, art, science, history and languages, a curriculum similar to that offered in boys' schools but not typically taught by governesses (Sayers 1973, p. 5). The company founded two new public, nondenominational girls' schools in West London in 1873: Chelsea High School and Notting Hill High School. The company accounts show the rapid development of the scheme: Croydon High School followed in 1874 and by 1891, 34 girls schools were operating with a total of 7011 pupils (Institute of Education Archive (IoE), GDS/5/1/1-21).

Notting Hill High School opened in Norland Square in September 1873 with ten girls aged 5 to 15 years old under the head mistress, Miss Harriet Morant Jones (Sayers 1973, p. 20; IoE, GDS/15/3/3). Miss Jones was an inspirational head mistress to both the girls (who nicknamed her affectionately, Jonah) and the other mistresses. She was recalled to Joan Wake by a former pupil and friend of Ethel Stokes as a 'cultured and intellectual woman of the world, had no degree, no connection with any university. She was just a remarkable woman, ...most of her girls felt there was no one in the world to be regarded with such reverence... as this head of ours, with the deep, resonant voice, steady brown eyes, almost stag-like carriage of her erect head on her slim elderly body' (NRO, Box 104). At Notting Hill High School, Ethel would have followed a timetable of daily prayers at 9.15, lessons from 9.30 to $1.15 \mathrm{pm}$, with a recreation break at 11.30 . The girls could dine in the middle of the day, and the afternoons from 2.30 to $4 \mathrm{pm}$ were spent on music, drawing and painting, and preparation for lessons (IoE, GDS/12/13/1, 3). The curriculum offered a rigorous academic education in French, German, Latin, Greek, arithmetic, mathematics, religious education, English grammar and composition, history, geography, science and book keeping, along with the accomplishments expected of girls such as drawing and music. Science was initially quite limited to 'natural history and objects', but science laboratories were built and all the sciences were taught by around 1900. In 1877, a new lecture hall was built to accommodate the three forms, and this was in use when Ethel was a pupil.

Ethel Stokes was typical of the school demographic. Most girls were from upper middle-class homes in the vicinity of the school, which according to Joan Wake's memoir was then 'squares and terraces of comfortable middle-class houses in nice gardens and with modest staffs of maids' (NRO, Box 104). The girls' fathers were 
merchants, or in the army, law, medicine, clergymen, teachers, bankers, engineers, stockbrokers (like Ethel's father) and manufacturers, with a large number of artists and architects, including Morris and Burne Jones (Sayers 1973, pp. 53-58). By 1885, most girls, like Ethel, came from private preparatory and other schools and some were governess-educated. Families had to be able to afford the fees of 15 guineas a year for girls over 15 years old and 12 guineas for younger girls. Ethel did well academically and was a regular recipient of school prizes, including for arithmetic, history, literature, French and German and was commended in Inspection Reports every year (NHEHS, School Magazine 1887-1890, Inspection Reports 1885-1889). She took the Cambridge Local Examinations, only recently opened to girls, in December 1887, seniors Class 1, and achieved distinctions in scripture, English and German, followed by Higher Local Examinations in 1889 (NHEHS, School Magazine 1887-1890, Admissions Register). Notting Hill High School had established a reputation for excellence as the girls regularly took top marks and secured scholarships for university colleges at Cambridge (Girton, Newnham), at Oxford (Somerville), Aberystwyth and in London (Bedford, Royal Holloway and University College) (Sayers 1973, pp. 112-120).

Later, some of her school friends reminisced in letters written to Joan Wake about their time at Notting Hill (NRO, Box 104). Maud Simkins recalled Ethel as 'the jolliest little school-girl, good at games and good at work, not particularly outstanding in any direction, sensible, whimsical face, neat short hair parted on one side of her bullet head, like a boy's', wearing 'skirts gathered at the waist...nice clean frills at neck and wrist', the 'homemade smocked frocks of hers were finished with very nice sashes', and 'very suitable strong shoes, always well kept'. Her style contrasted with other girls who put up their long hair and wore longer skirts. Ethel Stokes was one of the school librarians, serving on the school library committee with Cecile du Pontet (later Mrs Jordan) and Belle Lewis in 1888-1889 (NHEHS, School Magazine 1889). The school encouraged gymnastic exercise and societies for swimming, cricket and tennis, while hockey and football were played in the schoolyard (Sayers 1973, p. 71). Ethel was keen on games, 'Ethel and her set would be among the first to go in for cricket—greatly daring — and tennis'. Charitable work was encouraged, through the Charity Society, knitting and jersey groups and the Old Girls' Association, formed in 1885. Ethel seems to have absorbed the school's ethos of the 'desire to serve, making the most of life and its chances' with 'rightmindedness, clear sightedness, fairness' (NRO, Box 104).

\section{Record agent at the Public Record Office, London}

Ethel Stokes left Notting Hill High School in July 1889 to 'work for London degree' (NHEHS, Admissions Register). Although the 1891 Census describes her living with her brother and parents as a 'student' at the age of 21 , there is no evidence that she did study for a degree. Indeed, a school friend recalled to Joan Wake that 'she never had desired to go on to university life. I think that was part of her ineradicable independence of mind. She professed a kind of contempt for the academic ... she hurried on to find out the way for herself' (NRO, Box 104). Alice Mayes, who 
worked at the Public Record Office (PRO) on the New South Wales (Australia) Government Archive staff in the 1880s, later recalled that 'Miss Ethel Stokes appeared at the Public Record Office when she was, I believe, about 18, as a copyist on the New South Wales Government Archive staff under Mr James Bonwick, FRGS, Archivist' (NRO, Box 104). If she was 18, this would have been in 1888 or 1889, perhaps once she had left school. Mr Bonwick had been appointed archivist to the New South Wales Government in 1887, and he began a systematic transcription project under which copyists such as Miss Mayes and Miss Stokes were employed to work on records held at the PRO and their transcripts were reproduced for consultation in Australia. Between 1892 and 1901, the transcripts were edited for publication in the series Historical Records of New South Wales (O'Brien 2005, p. v). Thus, Ethel Stokes began to work as a record agent, copying, transcribing and translating records in the Public Record Office in Chancery Lane, London, the British Museum and later also working on parish, ecclesiastical, municipal and estate records around the country.

Another record agent, Miss de Alberti, recalled in a letter to Joan Wake that she first met Miss Stokes at the PRO aged about 21 (so in about 1891), describing her as having 'a close Eton crop, a plain up and down navy blue dress, and square-toed low-heeled shoes...she scorned all feminine frippery' and that 'she had a very pleasant, frank face, fine eyes, a nice smile and a charming voice' (NRO, Box 104). According to Miss de Alberti, by the 1890s, Miss Stokes had an office in Chancery Lane (NRO, Box 104). She lived in Euston Square during the period 1893 to 1899 (NHEHS, Old Girls Association). Miss Stokes's account books detail her daily work (NRO, Box 103). The earliest surviving (from 1896) gives for each day her client's name, the hours worked, sometimes the activity such as 'copying' or 'trans.' and the location ('@BM' or '@RO'). In 1896, Miss Stokes mainly worked for Mr Bonwick for 6 shillings a day and worked by the hour for Miss Walford, Mr Griffin, Mr Yeatman, Mrs Salmon and others. Mr Hardy appears as a client in July 1896. Miss Stokes regularly worked every day except Sundays and seldom took a holiday, although she did note a visit to the National Portrait Gallery 'with mother and my dearest', a trip to the river with her father and a short visit to East Anglia (to Ranworth and Lowestoft) 'with my dearest' in July. By the age of 26 years old, she was evidently a successful and busy independent record agent, earning her own living and skilled enough to train other women in records work. Lucy Drucker, a record agent who began copying despatches at the PRO in 1897, later recalled to Joan Wake that 'Miss Stokes asked me if I would care to take up record work, if so, she would help to train me, which she did' (NRO, Box 104).

There is no entry for Miss Stokes in the 1901 Census, but by 1902, she lived in Castellain Road, Maida Vale (NHEHS, Old Girls' Association). The 1911 Census shows that the house was occupied by her aunt Marion Baker and that Ethel Stokes and her mother Fanny lived there. Her brother Durham had his own household as noted above, and her father lived elsewhere: he seems to have been visiting a 40-year-old widow, Blanche Jones in Abbey Road, St John's Wood, on the census date in 1911. The other member of Miss Baker's household in 1911 was Mary Louisa Cox, a boarder, aged 37, recorded as a 'record agent'. She and Miss Stokes did work described as 'hunting up genealogies and other historic records in British 
Museum and other places' and both worked on their 'own account', i.e. they were women who earned their own income. Lucy Drucker recalled later that Miss Stokes lived in Castellain Road 'when I first knew her' and 'continued to do so until sometime after her partnership with Miss Cox when they decided to live together and Miss Stokes gave up the house and went to a boarding house in Bayswater' (NRO, Box 104).

\section{Stokes and Cox, record agents}

By 1903, Ethel Stokes had set up business at Lincoln Chambers, 75 Chancery Lane, London, with Mary Cox (1873-1936) (NRO, Box 103). Mary's father, Edward Cox, a law stationer, lived at 102 Chancery Lane with his wife Eleanor. Mary was the eldest child, born in 1873, and she had two sisters (Grace and Alice) and two brothers (Edward and Douglas). In 1881, the household included a governess, Emily Hibbit, and a servant (UK Census 1881). In 1891, all five children were described as 'scholars' (UK Census 1891). In 1901, four children still lived at home: Mary was an 'ancient records searcher', Grace a parish worker, Edward a law stationer's clerk (later a partner in his father's business) and Douglas an auctioneer's clerk (UK Census 1901). The surviving account and letter books for Stokes and Cox run from 1903 to 1937 (NRO, Box 103). The earliest volume, in Miss Stokes's neat hand, is arranged by client name, with notes of the hours charged for making copies and lists, the subject of the research, together with payments received on account, all carefully reconciled. The account books for 1911-1925 show a very large and growing number of private clients, together with preparing an index for the Record Commission Report for which Miss Stokes was paid $£ 36$ 11s. From 1919, the books also act as daily office letter books, in and out, and note the place at which Miss Stokes worked each day, mainly at the PRO, British Museum (BM) and Somerset House (SH). The books and associated letters give an impression of a very busy, highly organised record agency, with private clients around the world and work for official bodies. By the 1930s, Stokes and Cox had clients in the USA, Canada, Australia, Argentina, as well as around Britain and on the Continent. For instance, Stokes and Cox undertook legal searches for AH Thomas at the Guildhall Record Office, London; worked for James Young of New York on his ancestry; for WG Paton of Sydney, Australia about the Walker family; for W Maule Cole based in Burma about the Moray family; undertook genealogical searches for the investigators G y De Pablo of Buenos Aires; and in 1937 made an extensive search as part of a court case claim into the circumstances of a treaty made by the British army with the Thompson River Indians in British Columbia in 1858 (NRO, Boxes 235, 236). Miss Stokes was very meticulous about book keeping and correspondence, and while all her letters were handwritten, Miss Stokes made use of 'any other modern invention: telephone, taxi, typist she used them all', 'whatever she undertook would be swiftly and surely executed...to perfection too' (NRO, Box 104).

Stokes and Cox was a business partnership, but also personal one. They were close friends for 35 years, from around 1901 until Mary Cox died in 1936, and for most of that time they lived and worked together. The rooms at the top of 75 
Chancery Lane, over the road from the PRO, provided an office and a living space, with a gas ring in a recess behind a baize curtain, on which 'Miss Cox would prepare the food which nourished Miss Stokes'. Wake (1954, p. 2) describes the room as 'furnished with heavy Victorian furniture and a huge oil-painting of Miss Cox. Books and papers were stacked here and there in orderly piles'. Miss de Alberti later described Miss Cox as 'the woman friend she lived with, who was more domesticated than Ethel Stokes and attended to household matters' (NRO, Box 103). She was 'tall, well-built, handsome and more feminine' (NRO, Box 241). A school friend recalled to Joan Wake that 'Miss Cox had come to the rescue-for I seem to remember she [Ethel Stokes] had by then no feeling at all of care for her appearance' (NRO, Box 104). Miss Stokes took little interest in her personal appearance (describing herself jokingly as 'jolly hideous'), and she was 'always unconventional and ascetic in her way of life, comfort meant nothing to her' (NRO, Box 104). According to Joan Wake, 'Miss Cox did the few chaws there were to do and such charitable work as they both felt they owed the community and also took a minor share in the records business, and this left Miss Stokes free to devote her first class brain and prodigious powers of concentration to her professional work' (NRO, Box 103).

The partnership came to an end when Miss Cox died in 1936. Miss Stokes wrote to Miss Wake that 'Miss Cox had been definitely ill over four months but the heart trouble from which, very unexpectedly, she died quite suddenly began only 10 days ago. ... I am very, very thankful to have had 35 years with her.' (NRO, Box 103). Her work diary simply recorded 'Cox went to Royal N H[ospital]' on 28 May 1936 and then on 2 June 'MLC died' (NRO, Box 103). She was not one to make a fuss. After Mary Cox died, Miss Stokes went to live in a flat in Lissenden Mansions, NW5 with other women, which, she wrote to Joan Wake, 'makes a great difference having such kind co-mates in that flat; otherwise I should be entirely alone' (NRO, Box 103).

One of the most detailed cases researched by Stokes and Cox concerned Austrian refugees trying to reach England in the late 1930s. The work employed their professional skills, but the case also had personal connections. Miss Cox was involved with an organisation, Woman's Exchange and Anglo-Austrian Agency in the 1930s (NRO, Box 239) which acted as an employment agency for displaced women. It was associated with the work of the National Vigilance Association which campaigned on issues of public morality, traffic in women, prostitution and employment (Women's Library at LSE, 4NVA). Miss Cox had a number of friends living in Austria and Italy whom she visited from time to time. She sent parcels of books and magazines, such as the Illustrated Weekly, to her friend Mary Helena Zeppelin in Steiermark, Austria. Countess Zeppelin was the daughter of William McGarvey, a Canadian oil driller (Burr 2003). McGarvey drilled for oil in Galicia in Austria-Hungary, introducing the Canadian system of drilling to Europe, and built a refinery (later run by McGarvey's son, Fred). William McGarvey became a multimillionaire and with his wife entertained members of the European aristocracy in Vienna. In 1895, his daughter, Mary Helena, married Count Von Zeppelin of Graschnitz.

Miss Cox also corresponded with her friend Countess Stephanie Attems whose affairs in England she looked after (NRO, Box 239). Countess Attems was born 
Stephanie von Biedermann Túrony in 1880, in West Java, Indonesia, then part of the Dutch East Indies and a site of oil exploration. She lived in Gorizia, Italy, and in Vienna in the 1930s. After Miss Cox's death in 1936, Miss Stokes was in correspondence with Countess Attems about transferring her affairs to Mr Fred McGarvey's care and offered to send some souvenirs of Miss Cox to her. Countess Attems wrote to Miss Stokes, 'you were so much in her thoughts and mind when she was abroad. The feeling between you two was such a wonderful one' (NRO, Box 239).

In 1938, Fred McGarvey asked Miss Stokes to help find the documents needed to submit to the authorities in Vienna for the 'Aryan Certificates' for his sister (Mary) and Molly, reporting that 'it may be some time before our cases are dealt with' (NRO, Box 236). Whether the application was successful is not recorded. Miss Stokes also became involved in helping Edith Neuhardt to leave Vienna for England (all sources, NRO, Box 236). Mrs Neuhardt was born in 1899 in Hungary, but was a German (now Austrian) subject, well educated and well travelled. In 1938, she wrote to the Records Preservation Section hoping to find someone 'to help me out of the most horrible distress which I feel quite at a loss to describe'. Miss Stokes asked Mr Fred McGarvey to help Mrs Neustadt obtain a visa to leave Austria. Miss Stokes also involved the Society of Friends German Emergency Committee which had an office in Vienna. Mrs Neustadt wrote to Miss Stokes 'it is so good to trouble for me, an Austrian, just because your friend who passed away two years ago was so fond of Austria and spent such a happy time here'. Miss Stokes eventually arranged for her friend Mrs Doubleday to invite Mrs Neustadt to stay with her, but the application process suffered many delays, during which time Mrs Neustadt wrote increasingly anxious letters to Miss Stokes. In March 1939, Mrs Neustadt wrote to tell Miss Stokes that she had got permission to travel to England. However, Mr Doubleday became ill, so Miss Stokes arranged for Mrs Neustadt to stay with Lady Gregory as a companion instead (NRO, Box 236). Once in England, Mrs Neustadt tried to get visas for her "sister with husband and baby in Vienna who are anxiously waiting for me to help them out of Germany, as owing to conditions my brother-in-law cannot find any work there (he was a protégé of Schuschnigg) and these three are bound to starve'. She also wrote to Miss Stokes that she was concerned about her 'husband who cannot leave Germany just now' (NRO, Box 236). During the summer of 1939, Miss Stokes arranged a passage to Melbourne, Australia for Mrs Neustadt, writing to Lady Gregory 'I had no plans for her beyond wishing to enable her to be free again to be self-supporting which ... she was eager to be' (NRO, Box 236). Eventually, after much indecision, Mrs Neustadt sailed for Australia with the Peninsular and Oriental Steam Navigation Company in August 1939 (NRO, Box 236). The fate of the rest of her family in Vienna is not recorded.

\section{Charitable and voluntary activities}

Miss Stokes took an active interest in a number of charitable activities. According to Joan Wake (1954, p. 3), Miss Stokes apparently once went on a suffragette procession, but although unconventional she was not a suffragist. In 1895, she 
published a letter challenging women to fight for their country. She formed a band of volunteer women who were drilled for stretcher practice to help the Royal Army Medical Corps (RAMC). Eventually, Miss Wake recorded in her diary, she realised that the exercise was comical not practical and 'greatly to her relief' the band 'faded away' (NRO, Box 100). Miss de Alberti recalled in a letter to Joan Wake that the 'attempt to raise an army of women volunteers' was to counteract the presumption that 'women could not bear arms' (NRO, Box 104). The incident is perhaps an example of Miss Stokes challenging convention, rather than evidence of sympathy for the suffragettes.

During the First World War, Stokes and Cox organised a Ladies' Territorial Committee and a Glove Waistcoat Fund for 'gloves to be made into Windproof Waistcoats for Soldiers and Sailors' (NRO, Box 235). Sacks and bales of ladies' leather gloves were 'sorted, pieced together and stitched into wind-proof waistcoats' lined with leather for war workers 'facing the rigours of winter'. They also organised school girls to knit pieces which could be sewn into cardigans. The garments were then used 'to supplement the bales of socks, shirts and other things usually sent out' (NHEHS, School Magazine 1915). Stokes and Cox employed over fifty women who were 'too old or infirm to go out to work but were glad of the money' to do the work (NRO, Box 104), turning their office into what Miss Stokes described as 'a sort of Potash and Perlmutter', a reference to a popular play about the garment trade (NHEHS, School Magazine 1915). In 1914, Stokes and Cox also organised a scheme for a laundry service for territorials in camp to keep the men 'comfortable and in health'. A Local Ladies' Committee would be given a War Office Pass to collect washing from the camp, deliver it to the laundry, organise a party of local ladies to do any necessary mending and return the laundry to camp. These charitable enterprises for the war effort provided employment for women and were in keeping with the practical charitable ethos inculcated in Miss Stokes at school.

Miss Stokes was an active member of the Notting Hill Old Girls' Association, which she joined as soon as she left school. She attended meetings, speaking on several occasions about her work with records and writing in the School Magazine about researching a pedigree (1905) and family history as a hobby (1913) (NHEHS, School Magazine). She made many charitable donations, including in December 1936 to Forgotten Women, Seaman's Hospital, British Refugees from Spain, Winter Distress League, Ada Leigh Homes, Governesses' Benevolent Institute and Fairbridge Farm Schools (NRO, Box 103).

Miss Stokes also devoted time to the Boy Scouts Paddington District, acting as the Honorary Secretary from about 1916 or 1917. She had met Basil Richard Woollcombe, the Scout Commissioner and a solicitor 'in connection with his legal activities', perhaps through her legal records work (NRO, Box 104). She continued as Secretary until 1937 'when she retired at her own request owing to pressure of business' and was presented with a leather bound book of appreciation 'as an expression of our gratitude to you for the great services you have rendered ... during the last twenty-one years' (NRO, Box 103). However, during the Second World War she took up the role again when the new Secretary's firm was evacuated from London. Miss Stokes died as a result of a collision with a milk lorry as she was 
crossing the street on her way from Chancery Lane to a scout meeting in Paddington during the blackout in October 1944. Mr Clermont, Chairman of the Boy Scouts Association Paddington District, wrote later to Joan Wake that Miss Stokes 'was never late and as there was no phone call to explain her absence, we feared the worst and phoned the Police and then St Mary's Hospital ... I called at the hospital immediately but was not allowed to see her, not being a member of her family, but gathered that her condition was very serious' (NRO, Box 104).

At the time of her death, Miss Stokes was a Serving Sister of the Venerable Order of St John, an order of chivalry constituted by Royal Charter by Queen Victoria in 1888 to promote charitable work and Christian values. It was associated with voluntary service organisations, including St John Ambulance Brigade, and founded a hospice and dispensary. Members were divided into six grades from the Bailiff or Dame of the Grand Cross down to Esquire: Serving Brother or Sister is the fifth grade. Miss Stokes entered the Order as a Serving Sister in February 1934, having made a declaration of Allegiance. Her admittance cited her 'great authority on Medieval Latin and Old French'. She offered service through her work in the Order Library as well as general service (Museum of the Order of St John, Clerkenwell).

\section{Editing historical records and writing for historical works of reference}

Miss Stokes was closely involved in editing of records for publication by the British Record Society (BRS) and by county record and archaeological societies. The BRS was established in 1888 to edit and publish local records as well as indexes and genealogical finding aids, under the general editor WPW Phillimore, who also founded a publishing business. The foundation of record and archaeological societies in many localities from the mid-nineteenth century resulted in published editions of local records and promoted the study of local history. The PRO produced the great series of Calendars, the Rolls Series, Lists and Indexes. The PRO established an editorial tradition among its own staff engaged on this work and equipped scholars employed as freelance editors with historical skills. They included a few women, Mrs Everett Green and Miss Stokes, alongside male record agents and editors (Cantwell 1991, p. 334). Miss Stokes's editorial work ranged from abstracts of Prerogative Court of Canterbury Wills, several volumes for the BRS, a supplementary index of occupations for probate records (Spufford 1990, p. 124), translations of early court rolls of the manor of Wakefield (Barber 2014), State Papers of William III for the PRO (Cantwell 1991, p. 405), to transcriptions of early records of the Borough of Sudbury (NRO, Box 104), according to Lilian Redstone, the Suffolk record agent.

Around 1901-1902, Stokes and Cox embarked on a huge project to index parish registers before 1837 to help searchers find baptisms, marriages and burials 'when the locality is unknown'. Stokes and Cox employed researchers around the country, such as 'young people [wishing] to take up any career which meant using records', to copy parish register entries onto slips of paper, which were then compiled by Stokes and Cox into a General Index, held on cards so that it could be expanded. According to an advertisement for the Index, 'on payment of the fees, Stokes and 
Cox make the search themselves and report the results' (NRO, Box 104). Lilian Redstone was one of those young researchers who 'got their first knowledge of parish registers and the like from working on her [Miss Stokes'] gigantic General Index' when she copied out Woodbridge, Suffolk parish registers. She recalled to Joan Wake that 'the evenings at Maida Vale were spent in sorting that index. Eventually it became so large that it threatened to occupy the best part of the time of Stokes and Cox and they sold it' to Phillimore (NRO, Box 104). By the third edition, the Index included over two million entries from over 600 parishes around the country and was a major finding aid for genealogical research.

For over forty years from the turn of the twentieth century, Miss Stokes worked with HA Doubleday, a publisher and genealogical researcher, on two great national literary enterprises which required extraordinary levels of expertise and persistence: the Victoria County History of England and the Complete Peerage.

\section{Victoria County History}

Miss Stokes was involved in research and writing for several volumes in the Victoria History of the Counties of England ( $\mathrm{VCH})$, under the guidance of its founding editor, HA Doubleday (1867-1941). Doubleday later recalled the circumstances of the foundation of the $\mathrm{VCH}$ in 1899, the great historical enterprise edited by GL Gomme and Doubleday and published by Archibald Constable \& Co, owned by Doubleday (NRO, Box 240; Maclagan 2014). Described as 'a National Survey... tracing... the story of England's growth... into a nation which is now the greatest on the globe', $\mathrm{VCH}$ reflected the nineteenth century interest in local and national history and the development of scientific history in the universities (Beckett 2013, pp 8, 11). A Records Committee brought university experts together, a mark of the shift from amateur antiquarianism to more scientific approaches to history. It included Deputy Keeper Henry Maxwell Lyte, and the historians, J Horace Round, F Maitland and WH Stevenson (Beckett 2013, p. 14). Doubleday approached leading antiquaries (such as WH Farrer in Lancashire) to be local county editors, responsible for recruiting county committees and local writers (Beckett 2013, p. 14). However, there were difficulties in engaging suitable local writers for the parish histories. Round, Maxwell Lyte and Doubleday (having consulted Miss Stokes) concluded that 'very few local people were competent for this task and yet fewer had facilities to undertake it because they were too remote from London where most of the records were' (NRO, Box 240).

WJ Hardy and William Page, the record agents, were engaged by the VCH to employ record searchers who would find and copy sources at the British Library and PRO to be sent to local historical writers (Beckett 2013, p. 24). It quickly became clear that 'in order to exhaust the records for any one county it was necessary to calendar whole classes of records for all the counties simultaneously', a very largescale task (Beckett 2013, p. 24). Doubleday recalled that 'we had been forced to the conclusion that the only solution of the problem was this. We must try to get together a staff of post-graduate women students who had specialised in history and had some acquaintance with records and have them trained to compile the histories 
from extracts from the original sources to be supplied by Messrs Hardy and Page' (NRO, Box 240). Page, having been co-editor for the first volume of Hertfordshire, became the general joint editor with Doubleday (Lewis 2008) when 'his first task would be to select, train, and organise a staff of research workers qualified to provide the detailed studies of towns and villages which are the core of the work' (NRO, Box 240).

Page recruited women to undertake research for topographical entries 'searching of catalogues in the PRO and elsewhere', providing what Lewis (2008) described as 'Page's school of local history at the VCH'. The researchers noted place names from PRO Calendars and HMC Reports onto paper slips. At the end of each day, the researchers returned to Constable and Co's offices in Orange Street with the index slips and collated them by parish (Beckett 2013, p. 25), a process similar to that used by Stokes and Cox for their General Index. Eventually, when a county set was ready, it was sent to the county editor (Pugh 1970, p. 4). For counties remote from London, researchers also calendared and abstracted the records for the local writers. According to Beckett, 'Eleven women were employed in that work, and their numbers caused trouble at the PRO. In the autumn of 1904 SR Scargill-Bird, one of the PRO Keepers and a member of the VCH Records Committee, warned Page that "the presence of so many ladies employed on the Victoria County Histories in the Legal Search Room is I am sorry to say causing great inconvenience to the general public and I therefore write to you, privately in the first instance, to ask whether you can reduce the number to more practicable limits". Page was noncommittal in his reply and by May 1905 the VCH had 15 workers regularly in the PRO' (Beckett, 2013 , p. 26). One of those women was Lilian Redstone who was employed by VCH from 1904 to 1909. She remembered that Miss Stokes was already 'absorbed into the work of the Victoria County History' when she began there (NRO, Box 104). She recalled to Joan Wake that Miss Stokes was 'organising the wholesale taking of notes at PRO and set up the newcomers to work upon abstracting inquisitions post mortem, feet of fines and the like. She was also acting as sub-editor to topographical sections, reading parish histories and revising them with the inexperienced compilers'. 'It soon became more than one person could do with so rapidly expanding a staff ... we were divided up into groups under 'supervisors' a little later'.

The women were also employed to write the general essays for the introductory volumes and 'women writers became the mainstay of contributions on ecclesiastical, economic and social, and political history' (Beckett 2013, p. 27). The women included Elizabeth Anne Hodge, Constance Toulmin, Audrey Amy Locke and Ada Hendy (Beckett 2013, pp 18, 24, 28). Over 100 women were employed in the first two decades. Beckett (2013, p. 26) states that 'it was the availability of women which proved crucial to how $\mathrm{VCH}$ operated'. The qualities of the $\mathrm{VCH}$ which gave it 'the potential to stand at the leading edge of antiquarian and historical scholarship' (Lewis 2008) were its cooperative nature and national scope, the emphasis on 'the newly emergent science of archaeology and on economic history', the insistence that 'official records should be methodologically searched and buildings scientifically examined', its use of maps and the systematic uniformity of approach between counties (Pugh 1970, p. 4). Lilian Redstone recalled that 'She 
[Miss Stokes] and Miss Cox were then greatly interested in Essex and Canvey Island and she contributed some Essex material for VCH', published in VCH Essex II in 1907 (NRO, Box 104). Miss Stokes's involvement, however, seems to have diminished after Doubleday stepped down as editor in 1904 and then left as a director in 1907.

\section{The Complete Peerage}

Doubleday and Miss Stokes turned their attention to a new historical enterprise. GE Cokayne, a herald at the College of Arms, with the assistance of JH Round, had published the first edition of The Complete Peerage between 1884 and 1898 (Hammond 1998, p. x). Cokayne, working this time with Vicary Gibbs, a genealogist who was MP for St Albans between 1892 and 1904, began to prepare a revised edition. HA Doubleday had left Constable \& Co and the VCH in 1904 and moved to Bruges where he founded the St Catherine Press. Vicary Gibbs chose the St Catherine Press to publish the new edition of The Complete Peerage and Doubleday was closely involved, choosing the Caslon type, the paper and designing the layout. Doubleday became Assistant Editor in 1916 and Joint Editor in 1920 after Vicary Gibbs stepped down (Maclagan 2014; Hammond 1998, p. xv). Doubleday devoted himself to this enterprise, which he described as 'my sole interest in life', usually working 'at least six days a week and about ten hours a day' (Hammond 1998, p. xv). Miss Stokes wrote that it 'would have been brought to an end in an early volume but for his unquenchable enthusiasm and untiring efforts' (Stokes 1942). Doubleday increased the amount and quality of research and ensured that The Complete Peerage became a standard work of reference for those investigating peerage claims and genealogies. Funding came from subscriptions and various sponsors, including Lord Nuffield who gave $£ 50,000$ and a grant from the Pilgrim Trust. Doubleday fell ill in 1938 but continued work until his death in 1941, ensuring the publication of Volume $\mathrm{X}$.

Miss Stokes was one of a small number of researchers and editors to work closely with Doubleday. She was first credited in Volume VI (1926, p. ii), when 'the editors desire also to make special mention of the services of Miss Ethel Stokes in connection with research'. By the next volume (VII in 1929, p. v), the editors wrote that she 'has contributed much of value to nearly every article', and by 1932 (VIII, p. v) she 'has supplied many of the articles and done notable work on nearly all of them'. Her final contributions were published in Volume XI $(1949$, p. v) where 'the articles on medieval baronies up to and including St Maur are mostly hers'. Her own papers include carefully annotated bundles of letters, notes and draft articles arranged by letter ('The O group') and by name (Orreby, Ormond, Offaly, Plessetis) (NRO, Box 238-239, 241). Miss Stokes was consulted by Doubleday about all kinds of detailed issues to do with preparing the text for publication, finding typists, detailed notes on editing and corrections to drafts, allocation of work to different editors and catching up on work missed through illness. Doubleday wrote to her in 1939 that her 'new notes and other alterations have vastly improved the draft and you will see that all your alterations have duly gone in'. On another occasion they 
corresponded about how to deal with a contributor who has 'rather a good opinion of himself' so that 'he may not be cut down by criticism' (NRO, Box 238, 241). It does indeed seem that, as the introduction in Volume IX 1936 (p vii) stated, 'the editors desire to express again their indebtedness to Miss Ethel Stokes whose indefatigable industry and wide knowledge have been applied to nearly every page'. The professional relationship between them was also a 'firm personal friendship', shown by the help Mr and Mrs Doubleday gave in offering to house the Austrian refugee, Mrs Neustadt and in other correspondence between them. Miss Stokes wrote in her tribute to Doubleday 'there can never have been a more considerate employer and editor, a kinder or stauncher friend' (Stokes 1942). Miss Stokes had hoped to see The Complete Peerage to completion, but her work ended at letter $\mathrm{S}$ on her death.

\section{British Record Society, British Records Association and records preservation}

Miss Stokes's formal place in archival history rests on her role as founder in 1929 of the Records Preservation Committee, forerunner of the British Records Association. Since subscribing in 1901, Miss Stokes had been active in the British Record Society (BRS) (LMA, ACC/3162/BRA/1/1). After the First World War, legal and estate records were at risk of destruction following the abolition of manorial tenure in 1922 and the extension of land registration in 1925 (Harris 1989, p. 3). The Master of the Rolls Manorial Documents Committee drew up rules for the preservation of manorial records in 1926 and sent out inspectors to advise on the approval of local repositories (UK The National Archives (TNA), HMC 5/1). A British Academy conference on local war records in 1920 called for their preservation and classification by local societies. Throughout the 1920s, the Congress of Archaeological Societies, convened by the Society of Antiquaries, regularly discussed the problems of local historical, archaeological and record societies (LMA, ACC/3162/BRA/1/2; Shepherd 2009, pp. 74, 131-133). The Institute of Historical Research and the Anglo-American Conference of Historians took an interest in the migration of manuscripts and the accessibility of local archives in the late 1920s, carrying out two major surveys of local records (TNA, HMC 1/182, 185, 186).

Joan Wake recalled that Miss Stokes had discussed with her friend Maud Simkins her idea of a 'great scheme which had been slowly hatching in her mind, a scheme for the preservation and better treatment of local records on a nation-wide basis' and her proposal to set up an organisation 'to deal with records from every angle' which would go beyond the work of the British Record Society (NRO, Box 104). Miss Stokes was Secretary of a BRS Committee charged in 1928 with obtaining more funding for editorial work, but she took the opportunity to propose her larger vision for English archives (NRO, Box 103; LMA, ACC/3162/RPS/2/1/ 1). She wrote a report which proposed 'a nationally useful' society for 'organised work throughout the country', 'to support, consolidate and coordinate the work of local and special societies' as members of a national society, 'to advise owners and 
custodians of records and historical papers' and 'to secure the establishment of local record offices' so that 'our splendid heritage of records should be preserved and properly valued' (LMA, ACC/3162/BRA/1/1). Miss Stokes sent her scheme to influential people including Lord Hanworth, Master of the Rolls. She secured the support of Professor Frank Stenton (who was also a friend of Wake's), and AE Stamp, Deputy Keeper of the PRO. The Times published an editorial and article supporting the scheme for the preservation of records in June 1929. Some were not in favour, such as the Librarian of the Institute of Historical Research, Guy Parsloe, who feared a 'waste of energy which must result from overlap' (LMA, ACC/3162/ RPS/2/1/2). However, most were enthusiastic, and the momentum was unstoppable: the scheme was launched in 1929 and work started immediately (Harris 1989, pp. 4-5). A Records Preservation Committee was established by the BRS in 1930 to supervise the work and provide a 'centre for the reception and distribution of unwanted documents'. William Le Hardy, of record agents Hardy and Page, chaired the Committee, provided a room at 2 Stone Buildings, Lincoln's Inn and arranged for one of his staff, Annie Attwood, to help Miss Stokes and the other volunteers with the sorting and listing of records. In 1931 the Carnegie Trust gave a grant for three years.

In 1929, the Congress of Archaeological Societies had approved a proposal from the BRS in effect to support the new scheme by holding a Conference of Record Societies 'for the purpose of formulating a systematic scheme to deal with the practical questions that are daily arising in connection with the distribution of rescued documents' (LMA, ACC/3162/BRA/1/2). The First Conference of Record and Allied Societies and Depositories was held by the BRS in 1930, a grand affair at the Grocers' Hall in London with a reception hosted by the Master of the Rolls (Harris 1989, p. 7). A Second Conference in 1931, led to a committee being charged with drafting a 'constitution of future Conferences and of a permanent Committee' (LMA, ACC/3162/BRA/1/2, 3). The committee, chaired by Sir Matthew Nathan, included many of the prime movers of archives, William Le Hardy, GH Fowler, Hilary Jenkinson and Joan Wake. Fowler and Jenkinson drew up a memorandum for a new council to organise the 1932 Conference: Miss Stokes and Le Hardy were sent by the BRS to meet Jenkinson to discuss the proposal. Joan Wake wrote that it will be a mistake if the co-ordination of the work of Record Societies is mixed up with the organisation of the Conference, and that it will be better in every way if we can have an independent organisation in alliance with the BRS' (LMA, ACC/3162/ BRA/1/3). After a number of meetings, much correspondence and detailed discussion of draft constitutions, it was eventually agreed in 1932 to establish a new body, the British Records Association, 'to promote the preservation and accessibility under the best possible conditions of Public, Semi-Public and Private Archives', to rescue records at risk and distribute them to local custodians and to publicise 'record questions' (LMA, ACC/3162/BRA/1/1). In 1933, the Records Preservation Committee transferred from the BRS to become the Records Preservation Section of the new British Records Association (LMA, ACC/3162/ BRA/1/3).

The Records Preservation Committee, chaired by Miss Ethel Stokes, continued its work dispatching 'a great number of consignments of records to the appropriate 
repositories' while waiting for the new Section to be formed (LMA, ACC/3162/ BRA/1/1, 3). The move was not trouble-free, however, with significant differences of opinion over the handling of the Carnegie Trust grant money (LMA, ACC/3162/ RPS/1/4). In 1935, disagreements about the proper powers of the Records Preservation Section to publicise its work, communicate with its members and manage the volunteers, led to a threat by some committee members to reorganise the Section as an entirely separate body (LMA, ACC/3162/BRA/1/3). Miss Stokes resigned as Chairman in early 1936 'owing to ill health' but she became Honorary Secretary a few months later in succession to GE Nathan and was elected as the Section's representative to the BRA Council (LMA, BRA Council Minute Book, 1935-1938). Miss Wake resigned from the Committee too, but after a 'unanimous resolution expressing regret and the hope that she would reconsider', she did (LMA, ACC/3162/RPS/1/4). Miss Stokes quietly attended BRA Council every month to report on her work, asking for a new sorting table in 1936 and a cupboard for storage, and hoping for a typewriter (although funds did not permit this purchase until 1941) (LMA, BRA Council Minute Books, 1932-1946).

Miss Stokes established a huge network of over 300 hundred volunteers and workers around the country who rescued, registered, sorted and listed, and distributed archives to the localities in the interwar period. Many BRA deposits formed the core of embryonic local collections in a period when local archive services were being established. Between 1933 and 1939, the Records Preservation Section redistributed 270 archives to local repositories. The BRA records tell of tireless advocacy for archives and rescue work, mainly undertaken by Miss Stokes in the afternoons after the PRO closed and she finished her work as a record agent. The work rate steadily increased: 50 dispatches were made between October 1937 and April 1938, 81 in the six months from October 1938 to April 1939. In the final six months of 1939, 38 receipts and 91 dispatches of records were made (LMA, ACC/3162/RPS/1/7).

RPS work continued apace throughout the Second World War. Miss Stokes kept a detailed daily office diary for RPS from November 1940 until her death in October 1944, in which she noted dozens of letters written each week conveying advice, local records news, organising the RPS finances and meetings and dispatching records (LMA, ACC/3162/RPS/9/2/1). The destruction of records as waste paper salvage was a major concern and the subject of a publicity campaign (LMA, ACC/ 3162/RPS/9/2/1, RPS/7/2). Miss Stokes wrote to local Women's Voluntary Service groups and waste paper merchants, kept track of local paper and book salvage drives and sought the support of the national Director of Salvage, who was persuaded to issue a warning about the destruction of material of historical value (LMA, ACC/ 3162/RPS/9/2/1). In 1942, the Master of the Rolls broadcast a talk and Miss Stokes sent all 397 town clerks a leaflet about the dangers to records, especially rate books and poor law records, which were being inadvertently destroyed. Thousands of leaflets were printed and distributed. Miss Stokes continued to write all letters in her small neat hand (LMA, ACC/3162/RPS/9/2/1). The work took its toll on her as she persisted throughout the bombings of London, even though her room off Chancery Lane was destroyed and she lost most of her possessions. She no longer had the help and support of her partner, Miss Mary Cox who had died in 1936. She was 
periodically ill and on one occasion collapsed and had to be carried back to her room in Tooks Court. The Records Preservation Section office moved to 8 New Square, where she sometimes slept (LMA, BRA Council Minute Book, 1939-1942; Wake 1954, p. 6). She regularly did fire watching duty with staff at the PRO all night and according to Wake (1954, p. 6), 'for the last eight months of her life she slept on a mattress on the floor underneath a table in the library' at the PRO. After her death, Miss Stokes was succeeded as honorary secretary of the Records Preservation Section by Lilian Redstone, a member of the RPS Committee, formerly on the VCH staff and by the 1940s archivist for Ipswich and East Suffolk (who will be the subject of a separate article).

By the end of the Second World War, as a result of the combined efforts of the national network of voluntary committees of the Records Preservation Section under the guidance of Miss Ethel Stokes, records preservation work had achieved a national profile. She had helped to ensure the preservation of archives of great significance to local and national history and to rescue major archives which formed the core of many new county record services. At the AGM in November 1944, tributes were paid to Miss Ethel Stokes by the President of the BRA and Master of the Rolls, Lord Greene, the Deputy Keeper of the Public Records, Sir Cyril Flower, Keeper of the Department of Manuscripts at the British Museum, Dr Idris Bell, by Joan Wake and many others (LMA, BRA Council Minute Book, 1942-1946). The banker, Edward Hoare, BRA Treasurer, described her as 'one of the most loveable characters' and 'one of the greatest workers he had ever met'. Lord Greene spoke of her 'special knowledge and experience which very few possessed but an amount of labour almost incredible'. As her friend Joan Wake (1954, p. 7) wrote, Ethel Stokes was 'a great pioneer, a great leader, above all, a truly great woman'.

Open Access This article is distributed under the terms of the Creative Commons Attribution 4.0 International License (http://creativecommons.org/licenses/by/4.0/), which permits unrestricted use, distribution, and reproduction in any medium, provided you give appropriate credit to the original author(s) and the source, provide a link to the Creative Commons license, and indicate if changes were made.

\section{References}

Baggs AP, Bolton DK, Hicks MA, Pugh RB (1980) 'Friern Barnet: Introduction', in a history of the county of Middlesex: volume 6, Friern Barnet, Finchley, Hornsey With Highgate. In: Baker TFT, Elrington CR (eds) London, pp 6-15. http://www.british-history.ac.uk/vch/middx/vol6/pp6-15. Accessed 8 Mar 2016

Barber B (2014) Stokes, Ethel (1870-1944). Oxford Dictionary of National Biography, OUP. http://www. oxforddnb.com/view/article/106742. Accessed 5 Jan 2015

Beckett J, Bristow M, Williamson E (2013) The Victoria history of the counties of England: a diamond jubilee celebration 1899-2012. University of London, London

Burr C (2003) Some adventures of the boys: Enniskillen township's "Foreign Drillers," imperialism, and colonial discourse, 1873-1923'. Labour/Le Travail, pp 47-80, at https://journals.lib.unb.ca/index. php/LLT/article/viewFile/5293/6162. Accessed 24 Mar 2016

Cantwell JD (1991) The public record office 1838-1958. Stationery Office, London

Gibbs V (new ed) (1910-1959) The complete peerage of England, Scotland, Ireland, Great Britain and the United Kingdom: extant, extinct, or dormant. The St. Catherine Press, London

Hammond PW (1998) A brief history of the complete peerage. In: The complete peerage, vol XIV, pp xXviii 
Harris OD (1989) "The drudgery of stamping": a physical history of the records preservation section. Archives 19(81):3-17

Institute of Education Archive (IoE): Girls Public Day School Trust at GB/366/DC/GDS: GB/366/DC/ GDS/5/1/1-21. Annual reports and accounts (1872-1894); GB/366/DC/GDS/12/13/1. Prospectus Notting Hill and Bayswater High School (1898); GB/366/DC/GDS/12/13/3. Printed timetable Notting Hill and Bayswater High School (1873); GB/366/DC/GDS/15/3/3. Miss HM Jones, headmistress (1873-1900)

Lewis C (2008) William Page (1861-1934), general editor of the Victoria County History 1902-1934. Making History, IHR, at www.history.ac.uk/makinghistory/resources/articles. Accessed 15 Mar 2016

London Metropolitan Archives (LMA): British Records Association at ACC/3162: Uncatalogued, BRA Council Minute Books (1932-1935, 1935-1938, 1939-1942, 1942-1946); ACC/3162/BRA/1/1. Papers of Committee of the British Record Society leading to formation of BRA (1928-1932); ACC/3162/BRA/1/2. Pre-foundation papers (1930-1932); ACC/3162/BRA/1/3. Sir Charles Clay's file (1930-1932); ACC/3162/RPS/1/4. RPS Correspondence and minutes (1935-1951); ACC/3162/ RPS/1/7. BRA Standing committee reports (1937-1940); ACC/3162/RPS/2/1/1. BRA Correspondence (1928-1929); ACC/3162/RPS/2/1/2. BRA Correspondence (1929); ACC/3162/RPS/7/2. Wartime salvage file (1939-1945); ACC/3162/RPS/9/2/1. Miss Stokes' office diary (1940-1944)

Maclagan M (2014) Doubleday, Herbert Arthur (1867-1941). Revised PW Hammond, Oxford Dictionary of National Biography, OUP. http://www.oxforddnb.com/view/article/32865. Accessed $10 \mathrm{Mar}$ 2016

Northamptonshire Record Office (NRO): Joan Wake Collection at 1974/27, 355 boxes unlisted: Box 100. J Wake diary (8/1940); Box 103. Account book (1896-1897); Box 103. Account books, Stokes and Cox (1903-1927, 1911-1957); Box 103. Letter books, Stokes and Cox (1919-1922, 1923-1930, 1930-1937); Box 103. Letters from E Stokes to J Wake (4/6/1936, 24/12/1936); Box 103. Bound book presented by Paddington Boys Scouts Association (nd.); Box 103. Black note book, Stokes, 'British Record Society suggestions' (1928-1934); Box 103, J Wake ts draft memorial; Box 104. Letter from L Drucker to J Wake (22/11/1944), enclosing note from A Mayes (11/1944); Box 104. $\mathrm{J}$ Wake memoir ts note; Box 104. J Wake enclosures and memoir notes; Box 104. Letter from C Jordan to J Wake (12/8/1945); Box 104. Letter from de Alberti to J Wake (3/1/1945); Box 104. Letter from A Clermont, Chairman, Boy Scouts Association Paddington District, to J Wake (7/10/ 1950); Box 104. Letter from L Redstone to J Wake (6/5/1951) enclosing advertisement for the Index, (c.1901-1902); Box 104. Letter from AD Stokes to J Wake (6/11/1954); Box 235. Envelopes, bundles and files, mainly arranged by client name (c.1930s); Box 235. Ladies Territorial Committee photograph on printed notepaper (nd.); Box 236. Envelopes, bundles and files, mainly arranged by client name (c.1930s); Box 236. Letter McGarvey to E Stokes (1938); Box 236. Letters from E Neustadt, Vienna, to E Stokes (13/9/1938, 28/9/1938, 18/10/1938, 29/10/1938, 4/11/1938, 13/11/ 1938, 2/3/1939); Box 236. Letters from E Neustadt, Shoreham, to E Stokes (4/4/1939, 22/4/1939, 25/6/1939); Box 236. Letter from Society of Friends German Emergency Committee to E Stokes (3/ 2/1939); Box 236. Letters from Lady Gregory to E Stokes (20/6/1939, 8/1939); Box 236. Copy letter from E Stokes to Lady Gregory (23/6/1939); Box 236. Peninsular and Oriental Steam Navigation Company, Australia House, receipt for passage (4/7/1939); Box 238. Bundles of letters and notes about various families and peerages (c.1930s); Box 238. Letters HA Doubleday to E Stokes (1939); Box 239. Letter to M Cox (25/5/1935); Box 239. Letter F McGarvey to E Stokes (24/6/1936); Box 239. Letter from S Attems to E Stokes (18/7/1936); Box 239. Letters from F McGarvey to E Stokes (14/7/1938, 5/9/1938); Box 240. Paddington Boys Scouts Association, ts list of officers (1936-1937); Box 240. Copy letters about VCH dinner and ts account by Doubleday of VCH (1938); Box 240. Copy letter HA Doubleday to G Proby (7/5/1938); Box 241. Photograph (nd.)

Notting Hill and Ealing High School Archives (NHEHS): information accessed with the assistance of Liz Broekmann, Librarian and School Archivist: Admissions Register (1885); Inspection Reports (1875-1912); School Magazine (1887-1929); Old Girls' Association list of members (1890-1940)

O'Brien E (2005) Australian joint copying project: handbook. National Library of Australia, Canberra

Pugh RB (1970) VCH: its origin and progress. In: The Victoria history of the counties of England, general introduction. $\mathrm{VCH}$, London, pp 1-27

Sayers JE (1973) The fountain unsealed: a history of the Notting Hill and Ealing High School. Broadwater Press, Welwyn Garden City

Shepherd EJ (2009) Archives and archivists in 20th century England. Ashgate, Farnham 
Shepherd EJ (2016) Hidden voices in the archives: pioneering women archivists in early 20th century England. In: Foscarini F, MacNeil H, Mak B, Oliver G (eds) Engaging with archives and records: histories and theories. Facet Publishing, London

Ship passenger list indexes (accessed online, 24/2/2016): Narkunda (23/10/1925); Berengaria (3/8/1928); Christiaan Huygens (14/10/1932)

Spufford P (1990) The Index Library, a centenary history, 1988. In: Martin GH, Spufford P (eds) The records of the nation. British Records Association, London

Stokes E (1942) 'XIV'. Herbert Arthur Doubleday 1867-1941

UK, Civil Registration Birth, Marriage and Death Indexes (accessed online, 24/2/2016): 1870, 1871, $1873,1944,1957$

UK, National Census Index (accessed online, 24/2/2016): 1871, 1881, 1891, 1896, 1901, 1911

UK, The National Archives (TNA): Royal Commission on Historical Manuscripts at HMC/1 and HMC/5: HMC 1/182. Proposals for a General Survey or Census of Records (1920-1942); HMC 1/185. Correspondence with HMC on IHR's Sub-Committee on the Migration of Manuscripts (1927-1936); HMC 1/186. Correspondence with HMC on IHR's Sub-Committee to examine Mr Seymour de Ricci's plan to survey manuscripts in the UK (1934); HMC 5/1. Manorial Documents Committee minutes of meetings (1925-1934)

Wake J (1954) Ethel Stokes, a tribute. Northamp Past Present 2:3-9

Wollheim R (2004) Stokes, Adrian Durham (1902-1972). Oxford Dictionary of National Biography, OUP. http://www.oxforddnb.com/view/article/31722. Accessed 23 Mar 2016

Women's Library at LSE. 4NVA - Records of the National Vigilance Association

Elizabeth Shepherd is Professor of Archives and Records Management in the Department of Information Studies, University College London (UCL). Her research interests are in the history of archives and records management in the nineteenth and twentieth centuries and in the relationships between the management of records and information rights such as freedom of information and open government. She supervises doctoral and masters students and teaches on the MA in Archives and Records Management at UCL. 